\title{
STRATEGI PEMERINTAH DAERAH DALAM MEMPERTAHANKAN SUMBER DAYA PERIKANAN TANGKAP DI SUNGAI RUNGAN KOTA PALANGKA RAYA KALIMANTAN TENGAH
}

\section{LOCAL GOVERNMENT STRATEGY IN MAINTAINING CAPTURE FISHERIES RESOURCES IN RIVER RUNGAN, PALANGKA CITY, CENTRAL KALIMANTAN}

\section{Desy Selawaty \\ Ika Safitri Windiarti, PhD}

Muh. Ashari,.M.Si

Universitas Muhammadiyah Palangkaraya, Palangka Raya, Central Kalimantan, Indonesia

*email: ikasafitri@gmail.com

\section{Kata Kunci:}

Strategi I

Sumber Daya 2

Perikanan Tangkap 3

Sungai Rungan 4

dst

\section{Keywords:}

Strategy 1

Resource 2

Catch fisheries 3

Rungan River 4

Etc

\begin{abstract}
Abstrak
Tujuan penelitian ini untuk mengetahui Strategi Pemerintah Daerah Dalam Mempertahankan Sumber Daya Perikanan Tangkap di Sungai Rungan Kota Palangka Raya Kalimantan Tengah.

Penelitian ini menggunakan pendekatan kualitatif. Data penelitian ini diperoleh dari hasil pengamatan langsung, wawancara, dan mengumpulkan dokumen-dokumen pendukung. Adapun informan dalam penelitian ini adalah Dinas Perikanan Kota Palangka Raya, Dinas Kelautan dan Lingkungan Hidup Provinsi Kalimantan Tengah, Nelayan dan Masyarakat sekitar sungai rungan.

Hasil penelitian ini menunjukan bahwa strategi pemerintah daerah dalam mempertahankan sumber daya perikanan tangkap sudah cukup efektif dengan beberapa program yaitu penebaran benih ikan (restocking) disungai dan danau di kota palangka raya, pencegahan illegal fishing dengan pengaturan alat tangkap ikan, pembentukan Kelompok Masyarakat Pengawas (POKMASWAS) Ikan perairan Kota Palangka Raya, dan memberikan sanksi berupa pembinaan kepada masyarakat nelayan yang melakukan illegal fishing. dan mengembangkan konservasi dan rehabilitasi kawasan perikanan di sungai dan danau di Kota Palangka Raya. Kondisi eksisting sungai saat ini sudah mengalami penurunan kualitas air yang banyak di akibatkan oleh limbah perkebunan, illegal fishing dengan racun, tuba dan alat setrum, pelaku tambang emas dan pasir illegal. Dari jumlah produksi perikanan tangkap di Kota Palangka Raya mengalami penurunan tiap tahunnya yang diakibatkan degradasi lingkungan disungai dan danau sedangkan tingkat konsumsi masyarakat terhadap ikan selalu naik tiap tahunnya.
\end{abstract}

Abstract

The purpose of this study was to study the Regional Government Strategy to Maintain Capture Fisheries Resources in the Rungan River in Palangka Raya City, Central Kalimantan.

This research uses qualitative. The research data were obtained from direct observations, interviews, and collection of supporting documents. As informants in this study were the Palangkaraya City Fisheries Service, the Central Kalimantan Marine and Environmental Service, Fishermen and Communities around the Rungan River.

The results of this study indicate that the local government's strategy in maintaining capture fisheries resources is quite effective with several programs, namely the distribution of fish seeds (restocking) in rivers and lakes in the city of Palangka Raya, preventing illegal fishing using fishing gear, researchers of the Community Watch Group ( POKMASWAS) Fish fisheries in Palangka Raya City, and provide penalties in the form of fostering to the fishing community who conduct illegal fishing. and develop conservation and development of cultivation areas in rivers and lakes in Palangka Raya City. The current condition of the river has decreased water quality which is greater due to plantation waste, illegal fishing with poison, tuba and stun equipment, theft of gold mines and illegal sand. From the amount of capture fisheries production in Palangka Raya City, the decrease is decreasing every week due to environmental degradation in rivers and lakes while the level of community consumption of fish always rises every year. 


\section{PENDAHULUAN}

Pemerintah memiliki tanggungjawab dalam menetapkan pengelolaan sumberdaya alam untuk kepentingan seluruh masyarakat, dengan memperhatikan kelestarian dan keberlanjutan dari sumberdaya alam yang ada. Permasalahan lingkungan yang terus terjadi menyebabkan timbulnya permasalahan yang serius terhadap kondisi lingkungan, terutama lingkungan sungai. Permasalahan tersebut menyebabkan penurunan baik dari segi kualitas ataupun kuantitas lingkungan. Kegiatan masyarakat yang lebih dominan dilakukan di sungai terutama di Sungai Rungan Kota Palangka Raya Kalimantan Tengah, menyebabkan resiko yang signifikan terhadap kondisi sungai, terutama kondisi air dan biota yang terdapat di sungai.

Limbah dan Pollutan yang dihasilkan masyarakat, berdasarkan penuturan warga dan pengamatan langsung calon peneliti membuktikan bahwa sungai dijadikan sebagai Outlet buangan limbah dan pollutan masyarakat yang tinggal di sekitar sungai Rungan. Manusia dengan eksploitasi sumber daya lingkungan yang melebihi batas kemampuan akan mengalami penurunan kualitas bahkan menyebabkan kepunahan bagi biota yang tinggal di lingkungan sungai. Permasalahan yang dijumpai di lingkungan perairan sungai rungan antara lain penurunan kualitas air dan adanya kecenderungan penurunan hasil tangkap nelayan di sungai rungan. Kerusakan lingkungan dapat dilihat dari rendahnya keanekaragaman ikan dan jumlah ikan yang diperoleh oleh masyarakat setempat. Kerusakan sumber daya ikan di duga diakibatkan oleh kerusakan hutan alam, penangkapan ikan yang berlebihan dan penggunaan alat tangkap yang tidak ramah lingkungan seperti menggunakan racun, tuba, putas, alat listrik, pembakaran lahan yang dapat merusak kualitas air dan ekosistem lingkungan.

Masyarakat tradisional yang hidupnya bergantung pada Kawasan tersebut jika tidak mengelola dengan baik maka Kawasan tersebut akan mengalami degradasi lingkungan dan masyarakat akan kehilangan mata pencahariannya. Sumber daya perikanan air tawar memiliki peranan yang penting hal ini disebabkan oleh budaya setempat yang lebih terbiasa mengkonsumsi ikan perairan tawar dan harga ikan yang lebih murah. Tingkat kebutuhan ikan di Kota Palangka Raya yang terus meningkat mengingat tingginya permintaan ikan dari masyarakat yang semakin bertambah tingkat populasinya sehingga dapat mendorong peningkatan intensitas penangkapan ikan di Kota Palangka Raya yang mengancam keberlanjutan sumber daya ikan di perairan sungai.

Masyarakat dalam kegiatan penangkapan ikan disungai harus lebih memperhatikan kondisi lingkungan sungai dan jangka panjang keberlangsungan jenis dan populasi ikan. Kondisi sungai yang terjaga dari degradasi lingkungan membuat jumlah dan jenis ikan akan mudah ditemukan disungai, sehingga nantinya akan memberikan pemenuhan kebutuhan harian bagi masyarakat. Untuk itu perlu adanya peranan dari Pemerintah untuk mengatasi permasalahan yang terjadi di Sungai, khususnya Sungai Rungan Kota Palangka Raya Kalimantan Tengah. Permasalahan tersebut yang membuat peneliti tertarik untuk mengkaji lebih dalam mengenai bagaimana Strategi Pemerintah Daerah Dalam Mempertahankan Sumber Daya Perikanan Tangkap di Sungai Rungan Kota Palangka Raya Kalimantan Tengah.

\section{METODOLOGI}

Penelitian ini menggunakan pendekatan kualitatif karena metode penelitian kualitatif sebagai metode yang tepat untuk menjelaskan, menggambarkan dan menafsirkan hasil penelitian dengan susunan kata dan atau kalimat sebagai jawaban atas permasalahan yang diteliti (Herdiansyah, 2009) yaitu tentang Strategi Pemerintah Daerah Dalam Mempertahankan Sumber Daya Perikanan Tangkap di Sungai Rungan Kota Palangka Raya Kalimantan Tengah. Artinya data yang dikumpulkan bukan berupa angka- 
Desy Selawaty, Ika Safitri Windiarti dan Muh. Ashari. Strategi Pemerintah Daerah Dalam Mempertahankan Sumber Daya Perikanan Tangkap Di Sungai Rungan Kota Palangka Raya Kalimantan Tengah

angka, melainkan data tersebut berasal dari naskah wawancara, catatan lapangan, dokumen pribadi, catatan memo dan dokumentasi resmi lainnya.

Sumber Data Primer, yaitu:

I. Dinas Perikanan Kota Palangka Raya

2. Dinas Kelautan dan Perikanan Provinsi Kalimantan Tengah

3. Nelayan di Sungai Rungan

4. Masyarakat disekitaran Sungai Rungan.

Sumber Data Sekunder, yaitu:

I. Jumlah Jenis Ikan di Sungai Rungan

2. Jumlah penebaran jenis ikan di Kota Palangka Raya

3. Regulasi Perikanan Tangkap

4. Produksi Perikanan Tangkap

5. Anggaran Perikanan Tangkap

6. Jumlah POKMASWAS

7. Jenis Pelanggaran/Kasus Bidang Perikanan Yang Terjadi di Provinsi Kalimantan Tengah

8. Konsumsi rata-rata ikan di Masyarakat Teknik pengumpulan data yang digunakan yaitu :

I. Wawancara

Menurut Nasution (dalam Sugiono 2014:64) menyatakan bahwa observasi adalah dasar semua ilmu pengetahuan. Para ilmuan hanya dapat bekerja berdasarkan data, yaitu fakta mengenai dunia kenyataan yang diperoleh melalui observasi. Pengamatan (observasi) merupakan pengumpulan data secara langsung terhadap objek penelitian unuk memperoleh data yang valid dengan melakukan pengamatan langsung di Sungai Rungan Kota Palangka Raya Kalimantan Tengah

2. Observasi

Wawancara menurut Sutrisno Hadi (Sugiyono, 2007:192) adalah teknik yang digunakan untuk memperoleh data melalui percakapan langsung dengan informan.

3. Dokumentasi

Studi dokumen merupakan pelengkap dari penggunaan motode observasi dan wawancara dalam penelitian kualitatif. Studi dokumentasi merupakan salah satu cara yang dapat dilakukan peneliti kualitatif untuk menggambarkan dari sudut pandang subjek melalui suatu media tertulis dan dokumen lainnya yang dapat ditulis atau dibuat langsung oleh subjek yang bersangkutan.

\section{HASIL DAN PEMBAHASAN}

Penelitian ini membahas mengenai Strategi, maka peneliti menggunakan teori dari Jatmiko (2003) mendeskripsikan terdapat tiga faktor yang memberikan pengaruh terhadap strategi, yaitu:

a. Kemampuan Internal dan tujuan yang akan di capai

b. Sumber Daya

c. Lingkungan EksternaL

\section{Strategi Pemerintah Daerah dalam \\ Mempertahankan Sumber Daya Perikanan Tangkap di Sungai Rungan Kota Palangka Raya}

I. Penebaran Benih Ikan (restocking) di Sungai Kota Kota Palangka Raya

Tabel 1

Jumlah Penebaran Benih Ikan Restocking Di Kota Palangka Raya

\begin{tabular}{|c|c|c|}
\hline No & Tahun & $\begin{array}{r}\text { Jumlah Benih Ikan Restocking } \\
\text { di Kota Palangka Raya }\end{array}$ \\
\hline 1 & 2014 & 1.200 \\
\hline 2 & 2015 & 25.000 \\
\hline 3 & 2016 & 250.000 \\
\hline 4 & 2017 & - \\
\hline 5 & 2018 & 117.000 \\
\hline 6 & 2019 & \\
\hline
\end{tabular}

Tingginya aktivitas penangkapan ikan untuk konsumsi masyarakat, berdampak pada jumlah populasi ikan dilingkup sungai dan danau. Kegiatan semacam itu dilakukan setiap tahunnya sehingga tidak sebanding dengan 
jumlah ikan yang ada, sehingga jika dibiarkan terus menerus maka akan terjadi penurunan jumlah ikan di sungai dan danau.

Untuk mengatasi permasalahan terkait perikanan tangkap diperairan umum maka Pemerintah Kota Palangka Raya melakukan kegiatan restocking atau penebaran benih ikan tangkap di danau dan sungai perairan di Kota Palangka Raya, dengan harapan dapat membantu pengayaan jumlah bibit-bibit ikan lokal.

Dinas Perikanan Kota Palangka Raya melalui bidang Perikanan Tangkap menebar 45.000 bibit ikan sebagai upaya menjaga jumlah ikan di perairam umum di daerah setempat. Bibit ikan yang ditebar adalah Ikan Haruan atau ikan Gabus, dengan jumlah 20.000 ekor ditebar di Danau Burung, Kelurahan Petuk Ketimpun Kota PalangkaRaya dan 25.000 bibit ikan lainnya seperti lkan batok atau papuyu dan ikan jelawat ditebar di Danau Hanjalutung, Danau Burung dan Danau Buter. Penebaran benih ikan di lakukan di sungai dan danau di Kota Palangka Raya, penebaran benih ikan seperti jenis ikan patin, baung.

Dari data di atas setiap tahunnya mengalami kenaikan dari sisi jumlah benih ikan yang disebarkan disungai dan danau di Kota Palangka Raya dan pada table berikutnya dapat dilihat jumlah produksi perikanan tangkap yang dilkukan di sungai, danau dan rawa menurut kecamatan dan subsektor di Kota Palangka Raya.
Tabel : 2

Produksi Perikanan Tangkap Menurut Kecamatan dan Subsektor di Kota Palangka Raya (Ton), 20182019

\begin{tabular}{|c|r|r|r|r|r|r|r|r|r|}
\multirow{2}{*}{ No } & \multirow{2}{*}{ Kecamatan } & \multicolumn{7}{|c|}{ Produks Perikanan Tangkap (Ton) } \\
\cline { 3 - 10 } & & \multicolumn{2}{|c|}{ Sungai } & \multicolumn{2}{|c|}{ Danau } & \multicolumn{2}{|c|}{ Rawa } & \multicolumn{2}{|c|}{ Jumlah } \\
\cline { 3 - 10 } & \multicolumn{1}{|c|}{2018} & 2019 & 2018 & 2019 & 2018 & 2019 & 2018 & 2019 \\
\hline 1 & Pahandut & 262,10 & 236 & 275,60 & 193 & 230,50 & 195 & 768,20 & 624 \\
\hline 2 & Sebangau & 278,30 & 269 & 303,90 & 245 & 260,70 & 207 & 842,90 & 721 \\
\hline 3 & Jekan Raya & 286 & 187 & 310,50 & 197 & 253,10 & 139 & 849,60 & 523 \\
\hline 4 & Bukit Batu & 294,20 & 287 & 320,10 & 267 & 251,90 & 197 & 866,20 & 751 \\
\hline 5 & Rakumpit & 301,90 & 289 & 318 & 254 & 251,20 & 206 & 871,10 & 746 \\
\hline Palangak Raya & $1.422,50$ & 1.268 & $1.528,10$ & 1.156 & $1.247,40$ & 944 & 4.198 & 3.368 \\
\hline
\end{tabular}

Sumber: BPS Kota Palangka Raya

Dari table diatas mengalami penurunan jumlah produksi perikanan tangkap pada tahun 2019, hal ini terlihat dari jumlah sektor seperti sungai pada tahun 2018 sebanyak $1.422,50$ Ton sedangkan pada tahun 2019 sebesar I.268 Ton. Begitupula dengan perikanan tangkap di danau mengalami penurunan pada tahun 2018 jumlah produksinya 1.528,10 Ton sedangkan tahun 2019 berjumlah I.I56 Ton dan pada sektor rawa juga mengalami penurunan pada tahun 2018 berjumlah I.247,40 Ton dan pada tahun 2019 hanya berjumlah 944 Ton. Sedangkan konsumsi masyarakat terhadap ikan semakin meningkat tiap tahunnya hal ini sejalan dengan data yang peneliti dapatkan dibawah ini:

Tabel 3

Perbandingan Capaian Kinerja dari Tahun 2013 - 2016 Rata Rata Konsumsi Ikan di Masyarakat

\begin{tabular}{|c|c|c|c|c|c|}
\hline \multirow[b]{2}{*}{ Indikator Kinerja } & \multicolumn{4}{|c|}{ Capaian Kinerja (Ton) } & \multirow{2}{*}{$\begin{array}{c}\text { Kenaikan } \\
\text { Rata-Rata } \\
\text { per } \\
\text { Tahun } \\
(\%)\end{array}$} \\
\hline & 2013 & 2014 & 2015 & 2016 & \\
\hline $\begin{array}{c}\text { Rat-rata } \\
\text { Konsumsi ikan } \\
\text { masyarakat } \\
\text { (kg/kapita/tahun) }\end{array}$ & 46.03 & 46.51 & 46,35 & 47.09 & 0.77 \\
\hline
\end{tabular}

Sumber : Dinas Kelautan dan Perikanan Prov.Kalteng

Apabila dibandingkan dengan tahun sebelumnya maka ada peningkatan rata-rata 
Desy Selawaty, Ika Safitri Windiarti dan Muh. Ashari. Strategi Pemerintah Daerah Dalam Mempertahankan Sumber Daya Perikanan Tangkap Di Sungai Rungan Kota Palangka Raya Kalimantan Tengah

konsumsi ikan masyarakat Kalimantan Tengah sebesar I,60 \%. Hal ini menunjukkan bahwa tingkat konsumsi ikan masyarakat Kalimantan Tengah mengalami peningkatan. Peningkatan ratarata konsumsi ikan masyarakat Kalimantan Tengah pada juga dipengaruhi oleh peningkatan produksi perikanan. Dengan meningkatnya produksi perikanan akan mengakibatkan meningkatnya tingkat konsumsi ikan masyarakat,

- Hal ini ditandai dengan meningkatnya ratarata konsumsi ikan masyarakat menjadi sebesar 46,35 kg/kapita/tahun di Tahun 20I5, lebih tinggi daripada tingkat konsumsi ikan masyarakat tahun 2014 yang berada di angka 46,19 $\mathrm{kg} / \mathrm{kapita} /$ tahun yang mana selama 4 tahun terahir selalu menunjukkan trend kenaikan, serta selalu berada pada posisi di atas Angka Konsumsi Ikan (AKI) Nasional. Dampak dari tingginya rata-rata konsumsi ikan masyarakat ini antara lain tingkat kesadaran masyarakat akan pentingnya mengkonsumsi ikan sangat tinggi, meningkatnya kesadaran masyarakat akan nilai gizi yang terkandung dalam daging ikan untuk kesehatan, meningkatnya kemampuan masyarakat untuk membeli ikan dengan harga yang lebih terjangkau dari pada daging sapi.

I. Pencegahan Illegal Fishing

Praktik Illegal Fishing yang terjadi di Perairan umum Kota Palangka Raya yaitu menggunakan alat Setrum listrik dan Racun berupa tuba dan Putas. Ini adalah startegi kedua yang dilakukan para pemangku kepentingan dalam mempertankan sumber daya perikanan tangkap di Kota Palangka Raya.

I) Pengaturan Alat Tangkap

Alat tangkapan yang umumnya digunakan nelayan di Sungai Rungan yang dapat menangkap ikan dalam jumlah banyak dan berbagai macam jenis ikan dan ukuran yaitu :
a) Kabam (Traps)
b) Rawai (Long line)
c) Banjur (Stake line)
d) Rengge (Gill net)
e) Lukah/Bubu (Portable Traps)
f) Selambau (Seine net)
g) Jala/Lunta (Cash net)
h) Hancau (portable Lift net)
i) Jabak (Traps)
j) Beje (Pond traps)

Untuk di daerah Hulu Sungai Rungan, alat tangkap Selambau tidak dipakai oleh nelayan setempat karena alat ini tidak sesuai dengan daerah perairannya yang merupakan sungai-sungai kecil yang berarus agak deras. Sedangkan di bagian Tengah dan Hilir/Muara Sungai Rungan banyak Salambau digunakan oleh nelayan. Alat tangkap Mangumpe dan Beje umumnya dioperasikan pada musim kemarau (Juli - September ). Pada saat musim kemarau hanya badan air yang dalam yang berisi air yaitu sungai, danau dan lebung. Alat tangkap beje untuk menangkap ikan yang berada di lebung (Beje), sedangkan alat tangkap Mangumpe untuk menangkap ikan di perairan sungai atau danau.

Penggunaan alat tangkap ikan menggunakan racun dan listrik masih kerap terjadi di sungai rungan. Salah satu akibat penggunaan jenis alat tangkap ikan yang tidak diatur mengakibatkan penangkapan ikan berlebih seperti anak-anak ikan yang terjerat pada mata jaring yang kecil. Illegal fishing menjadi masalah utama dan rumit yang dihadapi pada sektor perikanan tangkap hingga kini.

Tabel 4 
Jenis Pelanggaran/Kasus Bidang Perikanan Yang Terjadi di Provinsi Kalimantan 7 Tengah Tahun 2016

\begin{tabular}{|c|l|l}
\hline No & \multicolumn{1}{|c|}{ Nama Kasus } & \multicolumn{1}{|c}{ Wilayah/Posisi Kast } \\
\hline 1 & Penggunaan alat tangkap yang di larang (Stroom) & DAS Kapuas \\
\hline 2 & Pengqunaan alat tangkap yang di larang (Stroom) & DAS Seruyan \\
\hline 3 & Penggunaan alat tangkap yang di larang (Stroom) & DAS Kahayan \\
\hline 4 & Penggunaan alat tangkap yang di larang (Stroom) & Perairan Lamandau \\
\hline 5 & $\begin{array}{l}\text { Penggunaan alat tangkap yang dilarang (Jenis } \\
\text { Lampara) }\end{array}$ & Perairan Kobar \\
\hline 6 & $\begin{array}{l}\text { Penggunaan alat tangkap yang dilarang (Jenis } \\
\text { Lampara) }\end{array}$ & Perairan Kobar \\
\hline
\end{tabular}

Sumber: Dinas Kelautan dan Perikanan Provinsi Kalimantan Tengah

2) Kelompok Masyarakat Pengawas

(Pokmaswas) Ikan Perairan Kota Palangka raya

Kelompok Masyarakat Pengawas

(Pokmaswas) di Kota Palangka Raya merupakan binaan dari Dinas Perikanan Kota Palangka Raya sudah ada di Kelurahan Panjehang, Petuk Barunai, Gaung Baru, Tangkiling, Mungku Baru, Kereng Bengkirai, Petuk Ketimpun dan lainnya.

Pokmaswas sendiri dibentuk agar dapat membantu pemerintah daerah kota palangka raya dalam menangani perikanan tangkap yang ada di sungai dan danau yang ada di Kota Palangka Raya. Pelaksanaan kegiatan SISWASMAS melalui pembentukan kelompok masyarakat pengawas (POKMASWAS). Berdasarkan data pada Bidang Pengelolaan Sumber Daya Kelautan dan Perikanan DINAS Dinas Kelautan dan Perikanan Provinsi Kalimantan Tengah, jumlah POKMASWAS yang telah terbentuk sampai dengan Tahun 2016 disajikan pada tabel berikut ini:

Tabel 5

Jumlah POKMASWAS yang telah terbentuk sampai dengan Tahun 2016

\begin{tabular}{|c|l|c|}
\hline No & Kabupaten/Kota & $\begin{array}{c}\text { Jumlah } \\
\text { POKMASWAS } \\
\text { (Kelompok) }\end{array}$ \\
\hline 1 & Pulang Pisau & 22 \\
\hline 2 & Kotawaringin Barat & 19 \\
\hline 3 & Kapuas & 5 \\
\hline 4 & Katingan & 19 \\
\hline 5 & $\begin{array}{l}\text { Kotawaringin } \\
\text { Timur }\end{array}$ & 6 \\
\hline 6 & Barito Timur & 2 \\
\hline
\end{tabular}

\begin{tabular}{|c|l|c|}
\hline 7 & Palangka Raya & 2 \\
\hline 8 & Barito Utara & 8 \\
\hline 9 & Sukamara & 6 \\
\hline 10 & Gunug Mas & 1 \\
\hline II & Serutan & 6 \\
\hline 12 & Barito Selatan & 0 \\
\hline I3 & Lamandau & 0 \\
\hline I4 & Murung Raya & 0 \\
\hline & Jumlah & 96 \\
\hline
\end{tabular}

Sumber: Dinas Perikanan dan Kelautan Provinsi Kalimantan Tengah

Melihat jumlah POKMASWAS yang telah terbentuk yaitu mencapai 96 kelompok, tentunya diharapkan mampu mengurangi terjadinya pelanggaran atau kegiatan yang merusak kelestarian sumber daya perikanan dan kelautan yang ada. Dalam hal penanganan tindak pidana perikanan masih memerlukan perhatian yang lebih besar dan dukungan serta koordinasi dari aparat dan masyarakat. Apabila dibandingkan dengan banyaknya kasus tindak pidana pelanggaran bidang perikanan yang terjadi dari Tahun 2012 - 2016, maka dapat dilihat pada tabel berikut ini:

Tabel 6

Perbandingan Jumlah Kasus Pelanggaran Bidang Perikanan di Provinsi Kalimantan Tengah Tahun 2012- 2016

\begin{tabular}{|c|c|c|c|c|c|c|}
\hline Uraian & $\begin{array}{c}\text { Tahu } \\
n \\
2012\end{array}$ & $\begin{array}{c}\text { Tahu } \\
n \\
2013\end{array}$ & $\begin{array}{c}\text { Tahu } \\
n \\
2014\end{array}$ & $\begin{array}{c}\text { Tahu } \\
n \\
2015\end{array}$ & $\begin{array}{c}\text { Tahu } \\
n \\
2016\end{array}$ & $\begin{array}{c}\text { Kenaika } \\
\text { n } \\
\text { Rata- } \\
\text { Rata } \\
(\%)\end{array}$ \\
\hline $\begin{array}{c}\text { Jumlah } \\
\text { Kasus }\end{array}$ & 3 & 7 & 8 & 15 & 5 & \\
\hline $\begin{array}{c}\text { Pelanggara } \\
\text { n Bidang } \\
\text { Perikanan }\end{array}$ & $\begin{array}{c}\text { Kasu } \\
\mathrm{s}\end{array}$ & $\begin{array}{c}\text { Kasu } \\
\mathrm{s}\end{array}$ & $\begin{array}{c}\text { Kasu } \\
\mathrm{s}\end{array}$ & $\begin{array}{c}\text { Kasu } \\
\mathrm{s}\end{array}$ & $\begin{array}{c}\text { Kasu } \\
\mathrm{s}\end{array}$ & $42,11 \%$ \\
\hline
\end{tabular}

Sumber: Dinas Kelautan dan Perikanan Provinsi Kalimantan Tengah

Jika dilihat pada Tabel 4.6 pada Tahun 2016 terjadi penurunan jumlah kasus pelanggaran tindak pidana di bidang kelautan dan perikanan sebanyak 10 (sepuluh) kasus $(66,67 \%)$ dari Tahun 2015 tetapi apabila dilihat dari kenaikan rata-rata kasus setiap tahun sebesar $42,11 \%$.

Hambatan yang terjadi dalam pelaksanaan kegiatan POKMASWAS di Kota Palangka 
Desy Selawaty, Ika Safitri Windiarti dan Muh. Ashari. Strategi Pemerintah Daerah Dalam Mempertahankan Sumber Daya Perikanan Tangkap Di Sungai Rungan Kota Palangka Raya Kalimantan Tengah

Raya yang diungkapkan Dinas Perikanan Kota

Palangka Raya yaitu masih minimnya anggaran dalam memberikan fasilitas berupa kapal, kelengkapan seragam, BBM terutama yang cukup kesulitan karena anggaran yang minim sehingga masih belum optimalnya pelaksanaan POKMASWAS ini di Kota Palangka Raya.

3) Sanksi bagi Pelanggar Illegal Fishing

Sanksi bagi pelanggar illegal fishing yang terjadi di sungai maupun danau hanya diberikan sanksi berupa pembinaan seperti penggunaan alat tangkap yang ramah lingkungan, ukuran ikan yang bisa di tangkap, bahayanya penggunaan alat tangkap yang merusak lingkungan bagi lingkungan sekitar. Dalam hal ini pemerintah berupaya mengatasi dan mengurangi terjadinya pelanggaran illegal fishing dengan memberikan sanksi berupa pembinaan yang melibatkan pemerintah dan kepolisian

2. Mengembangkan Konservasi dan Rehabilitasi Kawasan Perikanan

Tujuan dari Konservasi dan Rehabilitasi kawasan perikanan tangkap di perairan umum Kota Palangka Raya khususnya di sungai Rungan agar dapat melestarikan sumberdaya perikanan untuk meningkatkan stok alami sekaligus mencegah kepunahan spesies dan menjamin perkembang biakan itu berlangsung secara bertahap dan terus menerus.

Permasalahan dalam upaya konservasi sungai sebagai habitat ikan meliputi:

I) Sungai digunakan untuk berbagai kepentingan berbagai pihak.

2) Secara tradisional, nelayan tidak menguasai wilayah perairan sungai sehingga tidak mengontrol aktivitas di sungai
3) Masih terjadi penangkapan ikan di sungai menggunakan racun dan listrik pada musim air surut.

4) Sungai melewati batas-batas wilayah desa, sehingga pengelolaan tidak dapat bersifat lokal di suatu desa.

Sumber dana dari pelaksanaan Konservasi dan Rehabilitasi Kawasan Perikanan yaitu berasal dari APBD maupun APBN mendapat perhatian yang sangat besar dikarenakan program pemerintah daerah mendapat dukungan dari pemerintah pusat dalam hal ini Kementerian Kelautan dan Perikanan baik dari segi penganggaran maupun kebijakan sehingga terjadi sinergitas antara pemerintah daerah dan pemerintah pusat.

Dengan meningkatnya Kawasan konservasi perairan dan jenis yang dikelola secara berkelanjutan hal ini akan berdampak terhadap lingkungan antara lain:

I) Mengoptimalkan pemanfaatan wilayah perairan laut wilayah pesisir dan wilayah perairan umum daratan

2) Sumber daya ikan dapat terlindungi dan dilestarikan sehingga dapat dimanfaatkan dengan baik

3) Menjamin keberadaan ketersedian dan kesinambungan jenis ikan yang dikonservasi

4) Menjaga keseimbangan ekosistem di Kawasan konservasi Kalimantan Tengah

\section{Kondisi Eksisting Sungai Rungan}

Eksisting adalah kondisi mengetahui suatu keadaan secara nyata, jelas atau tampak seperti melihat kondisi fisik keadaan secara tampak, tampak lingkungan, dan kompetensi yang ada pada tampak.

Tambang emas yang dilakukan masyarakat di sungai bahkan danau di kawasan sungai rungan mengakibatkan pendangkalan pada air, serta pencemaran limbah air yang mengakibatkan kualitas air 
menurun dan membuat keberlangsungan ekosistem air mengalami kerusakan.

Beberapa penambang mengaku melakukan akttifitas penambangan karena tidak ada lagi pekerjaan setelah gejolak penurunan harga sawit, rotan maupun hasil perkebunan

Strategi pemerintah daerah Khususnya Kota Palangka Raya dalam menangani kasus ini yaitu dengan menetapkan Program Wilayah Pertambangan Rakyat (WPR) diharapkan dengan adanya WPR maka penambangan emas bisa dilokalisasi dalam satu kawasan yang dilegalkan melalui program WPR tersebut. Namun program ini masih belum bisa dilaksanakan karena terkendala penetapan wilayah yang masih belum selesai, terkait anggaran dalam pelaksanaan survei lokasi dan sebagainnya

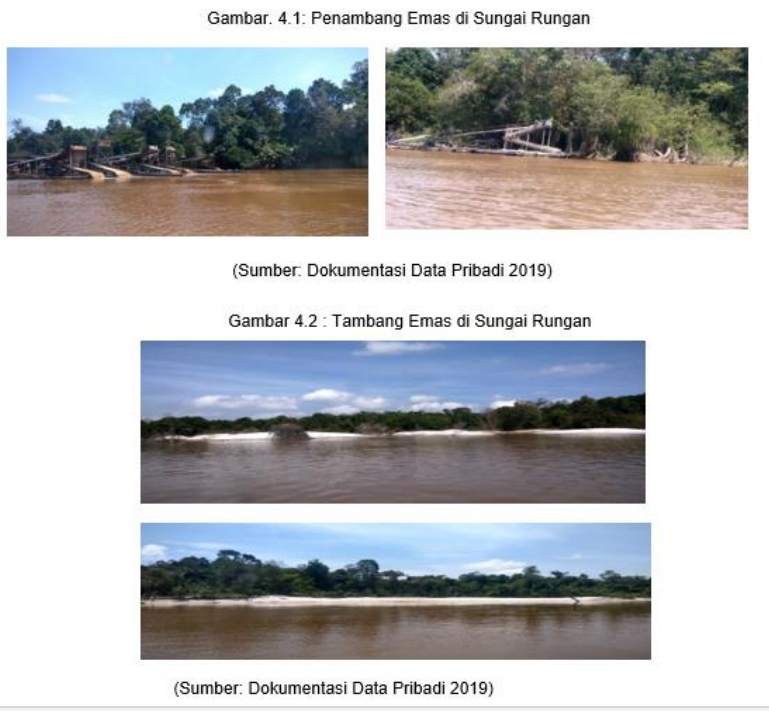

Belum adanya pemetaan perairan umum di Kota Palangka Raya padahal pemetaan perairan umum untuk memudahkan dan mengetahui kondisi perairannya yang masih terjaga dan yang sudah banyak mengalami kerusakan lingkungan, dengan adanya pemetaan ini kita mengetahui jenis ikan dan tumbuhan endemic apa saja yang ada dikawasan tersebut. Kondisi ekosistem di wilayah perairan umum yang terjaga akan berpengaruh terhadap hasil tangkapan ikan yang dilakukan masyarakat. Selain untuk mengetahui kondisi perairan, data hasil pemetaan ini juga bisa dimanfaatkan untuk promosi potensi investasi bidang perikanan. Kemudian wilayah perairan umum yang kondisinya masih terjaga juga bisa dijadikan Kawasan ekowisata. Pemetaan tersebut bisa berupa luas masing-masing danau dan kondisinya. Kemudian juga jenis ikan dan tumbuhan endemi apa saja yang ada dikawasan tersebut.

Tabel 7

Jenis Ikan Yang Ditemukan di Lingkungan Perairan Sungai Rungan

\begin{tabular}{|c|c|c|c|c|}
\hline No & $\begin{array}{c}\text { Nama } \\
\text { Indonesia }\end{array}$ & Nama Latin & Jurolah (Ekor) & Panjang $(\mathrm{Cm})$ \\
\hline 1 & Lais & Koupteperos macrocephalus & 18 & 32,21 \\
\hline 2 & Baung & Hecoibagous oemucus & 14 & 28,64 \\
\hline 3 & Basutia & Leigcassis micropogan & 1 & 11 \\
\hline 4 & Betutu. & Qxxuelogtris marmorata & 8 & 33,12 \\
\hline 5 & Gurami & Qsobroneronus goracosk & 5 & 20,2 \\
\hline 6 & Tambaksan & Helostoma Temominckii & 3 & 12,66 \\
\hline 7 & Jariali. & M9ascronathus maculatus & 1 & 22 \\
\hline 8 & Saogagna & Ruationlites bulu & 2 & 24 \\
\hline 9 & Rubiog & Scadosheileichthx abcasch & 2 & 14,5 \\
\hline 10 & Belida & Chitalaldoois & 2 & 31 \\
\hline 11 & Ratia & Pangasius pandarsius & 2 & 28,5 \\
\hline 12 & Jeman & 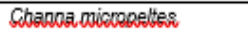 & 1 & 20 \\
\hline 13 & Gabus & Chanoa Striata & 1 & 25 \\
\hline 14 & Betok & Anabas testudineus & 1 & 10 \\
\hline
\end{tabular}

Sumber: Sweking, dkk. 2019

Faktor-Faktor Penghambat Sumber Daya Perikanan Tangkap Di Sungai Rungan Kota Palangka Raya

I. Ilegal Fishing

Kegiatan illegal fishing yang terjadi disungai rungan yaitu masih adanya penangkap ikan yang menggunakan alat tangkap yang dilarang seperti penyetrum listrik dan bahan beracun seperti tuba yang mengakibatkan jumlah bibit ikan berkurang karena mati, ikan-ikan mati, air menjadi keruh dan tidak dapat dimanfaatkan dalam kehidupan sehari-hari, ekosistem sungai terganggu.

Namun, dari ungkapan Kepala Bidang Perikanan Dinas Perikanan Kota Palangka Raya bahwa pelaku pelanggaran illegal fishing tersebut hanya diberi pembinaan yang melibatkan pemerintah dan kepolisian, serta pelaku juga 
Desy Selawaty, Ika Safitri Windiarti dan Muh. Ashari. Strategi Pemerintah Daerah Dalam Mempertahankan Sumber Daya Perikanan Tangkap Di Sungai Rungan Kota Palangka Raya Kalimantan Tengah

diminta membuat surat pernyataan tidak akan melakukan lagi. Maka dalam hal ini masih dirasa belum cukup sanksi yang diberikan kepada pelaku illegal fishing yang dilakukan sehingga mengakibatkan masih adanya pelaku-pelaku illegal fishing disungai rungan.

2. Penambang Emas Illegal di Sungai Rungan

Faktor penghambat berikutnya yaitu Penambang emas yang dilakukan masyarakat di sungai rungan, dari hasil penelitian yang peneliti dapatkan bahwa mereka melakukan penambangan ini dikarenakan tidak ada lagi pekerjaan setelah gejolak penurunan harga sawit, rotan maupun hasil perkebunan. Sehingga mereka beralih profesi menjadi penggali pasir dan emas illegal. Namun paling banyak yang peneliti temukan disekitaran sungai rungan dari petuk ketimpun, marang dan petuk bukit yaitu para penambang emas dan pasir illegal.

Strategi pemerintah daerah Khususnya Kota Palangka Raya dalam menangani kasus ini yaitu dengan menetapkan Program Wilayah Pertambangan Rakyat (WPR) diharapkan dengan adanya WPR maka penambangan emas dan pasir bisa dilokalisasi dalam satu kawasan yang dilegalkan melalui program WPR tersebut. Namun program ini masih belum bisa dilaksanakan karena terkendala penetapan wilayah yang masih belum selesai, terkait anggaran dalam pelaksanaan survei lokasi dan sebagainnya.

3. Belum adanya pemetaan lokasi periran umum di Kota Palangka Raya

Pemetaan potensi perairan umum di Kota Palangka Raya masih belum dilakukan hal ini dikarenakan terkendala anggaran serta kebijakan dan program pembangunan yang belum mengarah pada sektor perikanan tangkap dan pemetaan perairan umum hal ini diungkapkan langsung oleh
Kepala Bidang Perikanan Dinas Kota Palangka Raya.

Sedangkan pemetaan potensi perairan umum di Kota Palangka Raya sangat diperlukan untuk memperoleh gambaran dan data serta kondisi perairan dan ekosistemnya. Kondisi ekosistem di wilayah perairan umum yang terjaga akan berpengaruh terhadap hasil tangkapan ikan yang dilakukan masyarakat di Kota Palangka Raya. Selain untuk mengetahui kondisi perairan data hasil pemetaan ini juga bisa dimanfaatkan untuk promosi potensi investasi bidang perikanan dan wilayah perairan umum yang kondisinya masih terjaga juga bisa dijadikan Kawasan ekowisata.

Pemetaan tersebut dapat berupa luas masing-masing sungai, danau dan kondisinya, kemudian juga jenis ikan dan tumbuhan endemic apa saja yang ada pada Kawasan tersebut sehingga memberikan data yang pasti dan akurat. Dengan masih belum adanya pemetaan perairan umum sehingga menjadi kesulitan mengetahui jumlah ikan serta jenisnya di tiap-tiap sungai dan danau di Kota Palangka Raya.

\section{PEMBAHASAN}

Dari hasil penelitian yang peneliti temukan tentang strategi pemerintah daerah dalam mempertahankan perikanan tangkap di sungai rungan kota palangka raya provinsi Kalimantan tengah, maka dapat dijelaskan sebagai berikut ini:

I. Kemampuan Internal dan tujuan yang akan di capai

Strategi yang dilakukan pemerintah daerah Kota Palangka Raya melalui Dinas Perikanan Kota Palangka Raya dalam mempertahankan sumber daya perikanan tangkap di sungai rungan yaitu memiliki 3 strategi yang pertama, penebaran benih ikan atau restocking yang dilakukan disungai dan danau di Kota Palangka Raya dalam program ini sudah berjalan sejak tahun 2014 sampai dengan saat ini. Jumlah 
penebaran benih ikan mengalami kenaikan setiap tahunnya dari data yang peneliti temukan namun tiap tahunnya tidak semua lokasi sungai dan danau akan dilakukan penebaran benih ikan akan tetapi bergantian setiap tahunnya. Namun Hasil produksi perikanan tangkap di kota palangka raya mengalami penurunan setiap tahunnya sedangkan tingkat konsumsi masyarakat terhadap konsumsi ikan selalu meningkat tiap tahunnya. Hambatan yang ditemukan dalam penebaran benih ikan atau restocking yaitu masih adanya pelanggaran illegal fishing yang terjadi, serta limbah dari pertambangan emas yang dilakukan disungai rungan, dan limbah perkebunan yang mencemari kualitas air disungai rungan.

Kedua, pencegahan illegal fishing yang dilakukan Dinas Perikanan Kota Palangka Raya yaitu pertama melakukan pembinaan dan sosialiasi kepada masyarakat nelayan tentang penggunaan alat tangkap yang ramah lingkungan. Lalu dengan membentuk Kelompok Masyarakat Pengawas (POKMASWAS) Ikan Perairan Kota Palangka Raya. Kelompok Masyarakat Pengawas (POKMASWAS) di Kota Palangka Raya merupakan binaan dari Dinas Perikanan Kota Palangka Raya sudah ada di Kelurahan Panjehang, Petuk Barunai, Gaung Baru, Tangkiling, Mungku Baru, Kereng Bengkirai, Petuk Ketimpun dan lainnya. Pokmaswas sendiri dibentuk agar dapat membantu pemerintah daerah kota palangka raya dalam menangani perikanan tangkap yang ada di sungai dan danau yang ada di Kota Palangka Raya. Hambatan yang terjadi dalam pelaksanaan kegiatan POKMASWAS di Kota Palangka Raya yang diungkapkan Dinas Perikanan Kota Palangka Raya yaitu masih minimnya anggaran dalam memberikan fasilitas berupa kapal, kelengkapan seragam, BBM terutama yang cukup kesulitan karena anggaran yang minim sehingga masih belum optimalnya pelaksanaan POKMASWAS ini di Kota Palangka Raya.

Ketiga, mengembangkan konservasi dan rehabilitasi kawasan perikanan di sungai dan danau di Kota Palangka Raya. Tujuan dari Konservasi dan Rehabilitasi kawasan perikanan tangkap di perairan umum Kota Palangka Raya khususnya di sungai Rungan agar dapat melestarikan sumberdaya perikanan untuk meningkatkan stok alami sekaligus mencegah kepunahan spesies dan menjamin perkembang biakan itu berlangsung secara bertahap dan terus menerus. Hambatan yaitu sungai digunakan berbagai kepentingan berbagai pihak, nelayan tidak menguasai wilayah perairan sungai sehingga tidak dapat mengkontrol aktivitas disungai, masih marak terjadi illegal fishing, sungai melawati batas-batas desa sehingga pengelolaan tidak dapat bersifat lokal disuatu desa, dan masih adanya eksploitasi kayu hutan dipinggir sungai.

Kondisi Eksisting Sungai Rungan saat ini mengalami penurunan kualitas air yang diakibatkan pencemaran lingkungan yang diakibatkan pertambangan illegal yang dilakukan disungai rungan, illegal fishing, dan limbah-limbah perkebunan. Penurunan jumlah produksi ikan dan jenis ikan yang sekarang setiap tahunnya mengalami penurunan. Untuk penambangan illegal yang terjadi disungai rungan yaitu penambang emas illegal dalam hal ini pemerintah membuat program WPR Wilayah Pertambangan Rakyat (WPR) bersama Dinas Lingkungan hidup Kota Palangaka Raya dan diharapkan dengan adanya WPR ini para penambang emas illegal bisa dilokalisasi dalam satu Kawasan yang dilegalkan. Namun program ini belum optimal pelaksanaanya dikarenakan terkendalanya penetapan wilayah yang masih belum selesai dan terkait anggaran dalam pelaksanaan survey lokasi dan sebagainya”. Dinas Perikanan Kota Palangka Raya. 
Desy Selawaty, Ika Safitri Windiarti dan Muh. Ashari. Strategi Pemerintah Daerah Dalam Mempertahankan Sumber Daya Perikanan Tangkap Di Sungai Rungan Kota Palangka Raya Kalimantan Tengah

\section{Sumber Daya}

Sumber daya dalam strategi disini berupa sumber daya manusia, sarana dan prasarana dan anggaran biaya dalam pelaksanaanya. Pelaksana yang terlibat dalam kegiatan ini dari beberapa stakeholder seperti pemerintah kota yaitu Dinas Perikanan Kota Palangka Raya, Dinas Perikanan dan Kelautan Provinsi Kalimantan Tengah, Pokmaswas, dan Nelayan. Dukungan anggaran dalam pelaksanaan perikanan tangkap di Kota Palangka Raya menggunakan dana DPPA Dinas Perikanan Kota Palangka Raya, bidang perikanan tangkap dan sarana prasarana, pihaknya juga mendapat bantuan dari Balai Budidaya Air Tawar (BPBAT) Mandiangin, Kementerian Kelautan dan Perikanan Provinsi Kalimantan Selatan. Namun Sarana prasarana dalam pelaksanaan kegiatan POKMASWAS di Kota Palangka Raya yang diungkapkan Dinas Perikanan Kota Palangka Raya yaitu masih kurangnya fasilitas kapal, kelengkapan seragam, dan peralatan dalam pengawasan, BBM terutama yang cukup kesulitan karena anggaran yang minim sehingga masih belum optimalnya pelaksanaan POKMASWAS ini di Kota Palangka Raya.

\section{Lingkungan Eksternal}

Lingkungan eksternal adalah faktor-faktor luar (ekstern) yang dapat mempengaruhi pilihan arah dan tindakan suatu organisasi serta mempengaruhi proses internalnya. Strategi yang dilakukan Pemerintah Kota Palangka Raya dalam mempertahankan sumber daya perikanan tangkap khususnya di bidangi oleh Dinas Perikanan Kota Palangka Raya sudah banyak di dukung oleh berbagai pihak seperti kementerian kelautan dan perikanan Provinsi Kalimantan Selatan, Balai Budidaya, nelayan dan masyarakat sekitar sungai dan danau di Kota Palangka Raya. Dari hasil penelitian yang peneliti temukan tidak ada penolakan dari pihak lain terkait program-program yang sudah dilaksanakan oleh Dinas perikanan kota palangka raya.

\section{Model Pengembangan Perikanan Tangkap}

a. Reservart Perikanan (Pembuatan Rumah Ikan)

Reservart Perikanan atau pembuatan rumah ikan merupakan suatu bangunan berongga yang terususun dari benda padat yang ditempatkan dalam perairan yang berfungsi sebagai areal berpijah bagi ikan-ikan dewasa dan areal perlindungan, asuhan dan pembesaran bagi telur serta anak-anak ikan yang bertujuan untuk memulihkan sumberdaya ikan.

Reservart Perikanan merupakan suatu ekosistem perairan yang memiliki daerah yang terbatas, di mana semua kegiatan penangkapan biota perairan dengan cara apapun, kapanpun dan oleh siapapun, dilarang, karena memiliki fungsi sebagai tempat pelestarian ikan-ikan endemik yang langka (atau hampir punah) dan beberapa spesies yang dilindungi keberadaannya.

Reservat secara khusus merupakan tempat penelitian biota endemik yang langka, dan beberapa spesies yang hampir punah untuk dikembangbiakan dengan meneliti cara makan, beradaptasi, pemijahan, dan pakan alami dari larva sampai menjadi dewasa, agar bisa dikembalikan kembali ke habitat semula untuk menjaga keseimbangan ekosistem.Menurut Direktorat Bina 
Sumber Hayati tahun 1993 Pengertian secara umum reservat atau suaka perikanan adalah bagian dari perairan yang harus dilindungi, sehingga dilarang melakukan kegiatan penangkapan ikan, dan kegiatan-kegiatan lain yang dapat merusak lingkungan.

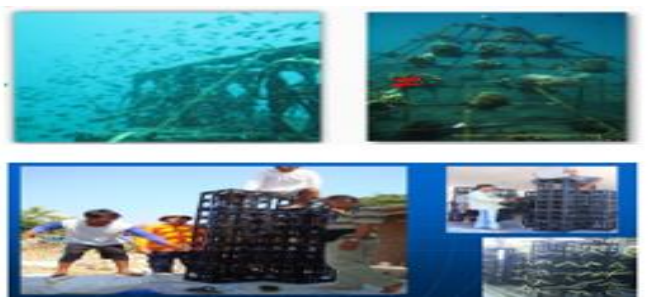

Gambar : Reservart Perikanan (Pembuatan Rumah Ikan)

b. Pembuatan Sumuran

Program lain untuk nelayan tangkap adalah akan membuat sumuran. Sumuran merupakan seperti kolam yang dibangun di daerah rawa dengan ukuran $2 \times 4$ meter dengan kedalaman 2 meter. Sumuran dibangun di daerah rawa, sehingga saat musim kemarau daerah rawa tersebut kering namun sumuran tetap ada air dan ikan terkumpul di daerah tersebut.

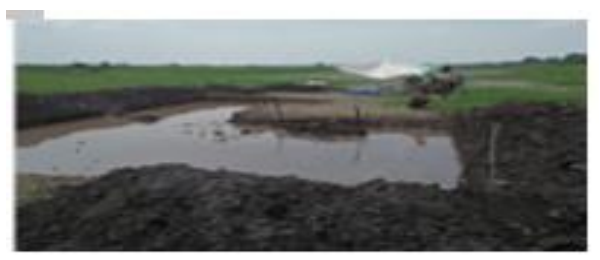

Gacolac:- Pembuatan Sumuran

\section{KESIMPULAN}

Dari hasil penelitian yang sudah dilakukan peneliti terkait Strategi Pemerintah Daerah dalam mempertahankan sumber daya perikanan tangkap di sungai rungan Kota Palangka Raya, maka dapat disimpulkan sebagai berikut:

I. Staregi Pemerintah Daerah dalam Mempertahankan pemerikanan tangkap di Sungai
Rungan Kota Palangka Raya yaitu Program penebaran benih ikan (restocking) di Sungai dan Danau di Kota Palangka Raya. Program restocking ini sudah berjalan dengan baik dari tahun 2014 2019 program ini dilakukan sebagai langkah melestarikan dan mengatasi kepunahan ikan lokal yang diharapakan memberikan manfaat bagi para nelayan dan masyarakat sekitar sungai. Pencegahan Illegal Fishing yang dilakukan pemerintah yaitu dengan mengatur alat tangkap ikan ramah lingkungan bagi masyarakat, membentuk Kelompok Masyarakat Pengawas (Pokmaswas) Ikan Perairan Kota Palangka raya dan memberikan pembinaan kepada para pelanggar illegal fishing. Selanjutnya pemerintah daerah melakukan pengembangkan Konservasi dan Rehabilitasi Kawasan Perikanan yang sudah berjalan namun masih belum optimal pelaksanannya.

2. Kondisi Eksisting Sungai Rungan saat ini telah mengalami degradasi lingkungan yang diakibatkan penambangan emas illegal disepanjang sungai rungan, limbah dari perkebunan, penangkapan ikan dengan menggunakan alat yang tidak ramah lingkungan menggunakan setrum listrik, racun seperti tuba dan putas sehingga mengakibatkan penurunan jumlah ikan di sungai rungan.

3. Faktor Penghambat dalam pemerdayaan perikanan tangkap disungai rungan yaitu masih terjadinya Illegal fishing, Illegal fishing menjadi masalah utama yang dihadapi pada sektor perikanan tangkap hingga kini. Penambang emas illegal dan belum terlaksananya pemetaan lokasi perairan umum yang terkendala anggaran sehingga kesulitan memperoleh gambaran serta data perairan dan ekosistemnya.

\section{SARAN}

I. Dinas Perikanan Kota Palangka Raya perlunya strategi baru dengan pembuatan Beje pada setiap rumah nelayan sekitar sungai rungan, Perlu diadakan dan pelatihan tentang 
Desy Selawaty, Ika Safitri Windiarti dan Muh. Ashari. Strategi Pemerintah Daerah Dalam Mempertahankan Sumber Daya Perikanan Tangkap Di Sungai Rungan Kota Palangka Raya Kalimantan Tengah

penggunaan alat tangkap ikan yang modern dan ramah lingkungan pada nelayan, perlunya pengawasan dan pemberian sanksi tegas bagi pelanggar illegal fishing dan pelaku perusakan lingkungan.

2. Menetapkan Program Wilayah Pertambangan Rakyat (WPR) diharapkan dengan adanya WPR maka penambangan emas bisa dilokalisasi dalam satu kawasan yang dilegalkan melalui program WPR tersebut. Melaksanakan program pemetaan lokasi perairan umum sungai dan danau

\section{UCAPAN TERIMA KASIH}

Puji dan syukur peneliti panjatkan kehadirat Allah SWT yang telah memberikan kemudahan kepada peneliti untuk menyusun dan menyelesaikan tesis yang berjudul "Strategi Pemerintah Daerah Dalam Mempertahankan Sumber Daya Perikanan Tangkap di Sungai Rungan Kota Palangka Raya Kalimantan Tengah”.

Dalam penyelesaian tesis ini, peneliti banyak mendapatkan bantuan dari berbagai pihak. Oleh karena itu peneliti menyampaikan ucapan terima kasih setulusnya kepada:

I. Bapak Dr. H. Muhamad Yusuf, S.Sos., MAP., Dekan Fakultas IImu Sosial dan IImu Politik Universitas Muhammadiyah Palangka Raya yang telah memberikan kesempatan untuk menempuh studi Magister Administrasi Publik.

2. Ibu Ika Safitri Windiarti, P.Hd selaku pembimbing I yang telah bersedia meluangkan banyak waktu untuk memberikan bimbingan dan arahan dalam penulisan tesis ini hingga selesai.

3. Bapak Muz.Azhari,.M.Si selaku dosen pembimbing II yang memberikan arahan dalam melakukan penulisan tesis ini.

4. Bapak dan ibu yang terlibat dalam pengambilan data yakni pihak Dinas Perikanan Kota Palangka
Raya, Nelayan dan Masyarakat di Sekitaran Sungai Rungan

5. Bapak dan ibu Dosen Pascasarjana serta pegawai FISIP yang telah banyak membantu dalam hal kelancaran dan kelengkapan administrasi sehingga penulisan tesis ini bisa berjalan dengan lancar.

Akhirnya Tesis ini dapat selesai dan peneliti berharap semoga Tesis ini dapat bermanfaat bagi semua pihak, untuk menambah wawasan khususnya bagi mahasiswa di Program Studi Magister Administrasi Publik Universitas Muhammadiyah Palangkaraya.

\section{REFERENSI}

Adnan, A., \& Solihin, S. (20I8). Keyakinan Masyarakat Adat dan Modernisasi di Kampung Adat Masyarakat Cireundeu Kota Cimahi. SosioPolitica, 8(I), 10-26.

Azfaiman, A. (2018). Peranan Dinas Perindustrian dan Perdagangan Kabupaten Kepulauan Meranti Dalam Memberikan Bantuan Modal Usaha Jenis Sagu Terhadap Pelaku Usaha Kecil Menengah (Doctoral dissertation, IImu Pemerintahan).

Brynson, John M. 200I. Perencanaan Strategis bagi Organisasi Sosial (terjemahan $M$. Miftahuddin). Yogyakarta: Pustaka Pelajar.

DESTINASARI, SISKA ENDAH, et al. Efektifitas Koagulan Biji Kelor Da Filtrasi Pasir Silika, Arang Aktif, Cangkang Kerang Dalam Menurunkan Kadar Besi (Fe) Dan Menetralkan $\mathrm{pH}$.(Studi Pada Air Sungai Di Desa Sejegi Kec. Mempawah Timur). 2018. PhD Thesis

Guyana, J. (20/3). Perumusan Strategi Bersaing Perusahaan yang Bergerak dalam Industri Pelayaran. Agora, I(3), III 5-1026.

Jatmiko.(2003).Manajemen Strategi. Malang: UMM Press

Juliansyah, E. (2017). Strategi Pengembangan Sumber Daya Perusahaan Dalam Meningkatkan Kinerja Pdam Kabupaten Sukabumi. Jurnal Ekonomak, 3(2), 19-37.

KUSUMA, E. (2019). Peranan Kepala Desa Dalam Pemberdayaan Masyarakat Terhadap Peningkatan Ekonomi Desa Bringin 
Kecamatan Montong Kabupaten Tuban (Doctoral dissertation, Universitas Bojonegoro).

Malik, I. K. (2019). Gaya hidup konsumtif di kalangan buruh pabrik: Penelitian di lingkungan masyarakat Desa Dawuan Barat Kecamatan Cikampek Kabupaten Karawang (Doctoral dissertation, UIN Sunan Gunung Djati Bandung).

Mujib, M. A. (2017). Aplikasi Sistem Informasi Geografis (Sig) Untuk Identifikasi Perubahan Sempadan Sungai Musi Di Kota Palembang (1922-2012).

Namawi, Handari. 2005. Manajemen Strategik Organisasi Non Profit Bidang Pemerintahan. Yogyakarta: Gajah Mada University Press

NISYAM, M. C. (20I4). Peningkatan Kualitas Layanan Dalam Usaha Bengkel Sepeda Motor Dengan Menggunakan Metode Quality Function Deployment (Qfd) Dan Perencanaan Pengembangan Strategi (Studi Kasus Bengkel Sepeda Motor Ud. Mekar Jaya Gresik) (Doctoral dissertation, Universitas Muhammadiyah Gresik).

Salusu, J. 2003. Pengambilan Keputusan Strategik untuk Organisasi Publik dan Organisasi Non Profit. Jakarta: PT. Gramedia Widia Sarana Indonesia.

Sembel, T., Gosal, R., \& Pangemanan, S. (2017). Partisipasi Masyarakat Dalam Pembangunan Desa (Studi di Desa Sinsingon Barat Kecamatan Passi Timur Kabupaten Bolaang Mongondow). JURNAL EKSEKUTIF, I(I).

Stephanie, K. Marrus. 2002 .Desain Penelitian Manajemen Strategik. Jakarta: Rajawali Press

Suraya, Ummi dan Haryuni. 2013. Evaluation of Fishery in Rungan River Cemtral Kalimantan. Jurnal Ilmu Hewani Tropika Vol 2. No. 2. Desember 2013

Sulistiyarto,Bambang.2008.Pengelolaan

Ekosistem

Rawa Lebak Untuk Mendukung Keanekaragaman Ikan dan Pendapatan Nelayan di Kota Palangka Raya. Tesis. IPB

Swaramarinda, D. R., \& Indriani, S. (20II). Pengaruh Pengeluaran Konsumsi dan Investasi Pemerintah Terhadap Pertumbuhan Ekonomi Di Indonesia. Jurnal Econsains, IX (2), 95- 105
Sweking, S., Najamuddin, A., Aunurafik, A. and Firlianty, F., 2019. Jenis dan Struktur Ukuran Ikan Yang Tertangkap di Danau Marang Kelurahan Marang Kecamatan Bukit Batu Kota Palangka Raya, Kalimantan Tengah. Agrikan: Jurnal Agribisnis Perikanan, I2(I), pp.I3-I7.

TANG, M. (2018). Analisis Penerbitan Perizinan Penyelenggaraan Toko Obat Pada Dinas Penanaman Modal Dan Pelayanan Terpadu Satu Pintu Kota Pekanbaru (Doctoral dissertation, Universitas Islam Negeri Sultan Syarif Kasim Riau).

Permana, Hermawan Dian.2019.Palangka Raya Miliki Potensi Bidang Perikinan. https://www.borneonews.co.id/berita/I274 I 4-palangka-raya-miliki-potensi-bidangperikanan. Diakses 5 Agustus 2019 Pukul II.33

Prasetyia, F. (20/2). Rekonstruksi Sistem Fiskal Nasional Dalam Bingkai Konstitusi. Journal of Indonesian Applied Economics, 5(2).

Putra, D. Y. (20II). Peran Sektor Perikanan dalam Perekonomian dan Penyerapan Tenaga Kerja di Indonesia: Analisis Input-Output. Universitas Andalas

Suraya, U. (20I3). Evaluasi Perikanan Tangkap di Sungai Rungan Kalimantan Tengah. Jurnal Ilmu Hewani Tropika (Journal Of Tropical Animal Science), 2(2), 75-82.

Syafei, I., Kamayani, M., \& Sinduningrum, E. (2019). Perancangan Aplikasi Pengaduan Masyarakat Terhadap Lingkungan Di Tingkat Kelurahan. In Prosiding Seminar Nasional Teknoka (Vol. 4, pp. IIII-II|6).

Ufrida, J., Basuki, F. R., \& Rahma, S. (20/8). Potensi Kearifan Lokal Geopark Merangin Sebagai Sumber Belajar Sains Di SMP. Edufisika: Jurnal Pendidikan Fisika, 3(0I), I-I6.

Welan, V. P. R., Kawung, G. M., \& Tumangkeng, S. Y. (2019). Peran Dana Desa Dalam Memberdayakan Ekonomi Masyarakat Desa Ranowangko Kecamatan Tombariri. Jurnal Berkala Ilmiah Efisiensi, 19(04).

Wijaya,Taufik.2016.Ternyata Nelayann Rawa Gambut Mampu Hidup Sejahtera Inilah Harapan mereka.

https://www.mongabay.co.id/2016/09/09/tern yata-nelayan-rawa-gambut-mampu-hidupsejahtera-inilah-harapan-mereka/. Diakses 5 Agustus 2019 Pukul II.50 
Desy Selawaty, Ika Safitri Windiarti dan Muh. Ashari. Strategi Pemerintah Daerah Dalam Mempertahankan Sumber Daya Perikanan Tangkap Di Sungai Rungan Kota Palangka Raya Kalimantan Tengah

http://sippa.ciptakarya.pu.go.id/sippa_online/ws_file/do kumen/rpi2jm/DOCRPIJM_0b08664647_BA B\%20IVBAB\%20IV\%20GAMBARAN\%20UM UM\%20WILAYAH.pdf

http://repository.umy.ac.id/bitstream/handle/ 2345678 9/10724/f.\%20bab2.pdf?sequence=6\&isAllow ed $=y$

Samrin. 2016. Pendidikan Karakter (Sebuah Pendekatan Nilai). Jurnal Al-Ta'dib. 9(I):I20143. 